\title{
HASIL TANGKAPAN DAN ASPEK BIOLOGI UDANG KELONG (Penaeus sp.) DI PERAIRAN BARAT ACEH
}

\author{
Wedjatmiko \\ Peneliti pada Balai Riset Perikanan Laut, Muara Baru-Jakarta \\ Teregistrasi I tanggal: 6 Oktober 2008; Diterima setelah perbaikan tanggal: 30 Januari 2009; \\ Disetujui terbit tanggal: 13 Pebruari 2009
}

\begin{abstract}
ABSTRAK
Penelitian ini dilakukan yaitu pada bulan Agustus 2005 dan Agustus 2006 di perairan barat Aceh. Pengamatan difokuskan pada hasil tangkapan dan aspek biologi udang kelong (Penaeus sp.). Hasil penelitian menunjukkan bahwa jenis jenis udang yang tertangkap di perairan barat Aceh diperoleh 20 spesies pada tahun 2005 dan 15 spesies pada tahun 2006. Jenis udang yang dominan tertangkap dan merupakan urutan pertama di perairan Aceh pada tahun 2005 adalah udang kelong, yaitu urutan pertama 36,1\% dan kedua pada tahun 2006, yaitu 18,1\%. setelah udang dogol (Metapenaeus ensis), $38,3 \%$. Udang kelong yang tertangkap di perairan barat Aceh tergolong mempunyai ukuran yang cukup besar dengan ukuran dominan $14,5 \mathrm{~cm}$ untuk udang betina, dan ukuran $11,5 \mathrm{~cm}$ untuk ukuran udang kelong jantan. Rasio udang jantan dengan betina adalah 1:2,1 (tahun 2005) dan 1:2,9 (tahun 2006). Di perairan barat Aceh, udang kelong lebih banyak tertangkap di perairan sekitar Kota Meulaboh,

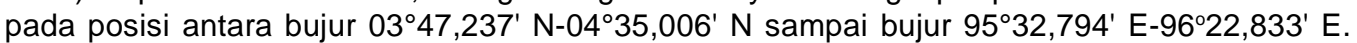

KATAKUNCI: $\quad$ populasi, aspek biologi, udang kelong, Perairan Barat Aceh

ABSTRACT: Catch and biological aspect of Penaeus sp. in western Aceh waters. By: Wedjatmiko

The research was conducted, on August, 2005 and August, 2006 in western Aceh waters (the same stasiun for two years). Observation was focused on population and biological aspect of udang kelong (Penaeus sp.). The Results show that there was 20 species of shrimps (2005) and 15 species (2006). Penaeus sp. a dominant species (36.08\%) on 2005 and $18.11 \%$ on 2006. Dominant size of Penaeus sp. were caught in Aceh waters ranged $13.0-15.0 \mathrm{~cm}$ (female) and $11.0-12.0 \mathrm{~cm}$ (male) respectively. Sex ratio of male and female of Penaeus sp was 1:2.1 (2005) dan 1:2.9 (2006). Distribution of Penaeus sp. in Aceh waters was in araund Meulaboh waters, at position of latitudes $03^{\circ} 47,237^{\prime} \mathrm{N}$ $04^{\circ} 35,006^{\prime} N$ and longituds $95^{\circ} 32,794^{\prime}$ E-96 22,833' $E$.

\section{KEYWORDS: catch, biological aspect, Penaeus sp., Western Aceh waters}

\section{PENDAHULUAN}

Jenis udang yang mempunyai nilai ekonomis penting dan sebagai komoditas ekspor, pada umumnya didominansi oleh genera Penaeus dan Metapenaeus. Udang Penaeus dikenal ada 2 kelompok, yaitu kelompok udang jerbung (Penaeus merguiensis, Penaeus indicus, Penaeus orientalis) dan kelompok udang windu (Penaeus monodon, Penaeus semisulcatus, Penaeus latisulcatus, dan Penaeus japonicus). Kelompok udang Metapenaeus dikenal sebagai kelompok udang dogol (Metapenaeus ensis, Metapenaeus lysianassa, dan Metapenaeus elegans). Jenis udang tersebut mempunyai nilai ekonomis tinggi, karena mempunyai ukuran yang relatif besar (kelompok udang jerbung) dan stok di perairan Aceh cukup melimpah (Naamin et al., 1992).

Indonesia mempunyai daerah penangkapan udang yang cukup potensial, menyebar hampir di sebagian besar perairan pantai Indonesia. Menurut Naamin
(1992), daerah penangkpan udang meliputi perairan barat Aceh (Aceh, Sumatera Utara, dan Sumatera Barat), sepanjang pantai timur Sumatera dan Selat Malaka (Aceh, Sumatera Utara, dan Riau), pantai utara Jawa (pantai utara Jawa Tengah), perairan Pantai Kalimantan (Kalimantan Barat dan Kalimantan Timur), Sulawesi (Sulawesi Selatan), perairan Maluku-Irian Jaya (Laut Arafura, Teluk Bintuni, dan pantai utara Irian Jaya).

Perairan barat Aceh merupakan daerah penangkapan udang, dengan luas wilayah penangkapan mencapai 900 mil $^{2}$ (Widodo, 1977). Salah satu jenis udang yang cukup melimpah di perairan Aceh adalah jenis udang kelong (Penaeus sp.), di mana menurut Suman et al. (1996) udang kelong (Penaeus sp.) tersebut adalah termasuk jenis udang windu. Sugeng (2005) mengatakan bahwa udang kelong ini sering dikenal sebagai udang putih (flower king) yang secara alami hanya ada di perairan Nanggroe Aceh Darussalam, lebih tepat berada di 
perairan Lamno, Aceh Jaya. Nama ilmiah udang ini belum ada, tetapi secara genetis seperti gabungan dari udang windu dengan jenis udang putih (Penaeus merguiensis). Saat dewasa, panjang dapat mencapai $30 \mathrm{~cm}$. Udang kelong tersebut juga sering dikenal sebagai white banana prawn atau bahasa latin dikenal sebagai Penaeus indicus (http://www. Omfi).

Menurut Badruddin \& Widodo (1974), udang yang tertangkap di perairan barat Sumatera digolongkan dalam 3 katagori, yaitu 1) white shrimp yang terdiri atas udang kelong, udang banana dan udang putih; 2) tiger shrimp yang terdiri atas Penaeus monodon dan Penaeus semisulcatus; dan 3) brown shrimpyang terdiri atas Metapenaeus monoceros, Metapenaeus spp., Metapenaopsis spp., Parapenaopsis spp., dan lain-lain. Hasil tangkapan ketiga kelompok udang tersebut, paling banyak adalah white shrimp (69,16\%) yang didominansi oleh udang kelong dan diikuti oleh brown shrimp (30,78\%), serta paling sedikit adalah kelompok tiger shrimp (0,06\%). Dengan demikian, udang kelong di perairan barat Sumatera memang dari dulu sudah banyak tertangkap secara dominan.

Secara morfologis, udang kelong mirip udang putih tetapi berwarna polos kecoklatan, mirip udang windu tetapi tidak bercorak (loreng), menurut Widodo (1977) dan setelah dikonfirmasi dengan Dr. Kasim Moesa, pakar ikan dan udang dari P2O-Lembaga IImu
Pengetahuan Indonesia, diyakini bahwa udang kelong tersebut adalah Penaeus monodon.

\section{BAHAN DAN METODE}

Penelitian telah dilakukan pada bulan Agustus 2005 dan Agustus 2006. Lokasi penelitian terletak di sepanjang perairan pantai barat Provinsi Nangroe Aceh Darusalam sampai perairan Sumatera Barat pada daerah perairan yang layak dilakukan penelitian dengan menggunakan alat tangkap trawl (trawlable). Peta lokasi penelitian dapat dilihat pada Gambar 1.

Penelitian dilakukan menggunakan KR. Bawal Putih yang dilengkapi alat tangkap udang atau ikan demersal (Gambar 2). Alat tangkap yang digunakan adalah pukat dasar (bottom trawl) yang dioperasikan dengan kecepatan tarik (towing speed) sekitar 3 knot selama 1 jam (60 menit). Informasi mengenai posisi titik pengambilan contoh menggunakan global positioning system tipe Garmin global positioning system 45. Informasi kedalaman perairan diperoleh dari Scientific Echosounder SIMRAD EK 60.

Hasil pengambilan contoh berupa ikan dan udang disortir dan diidentifikasi menggunakan buku identifikasi menurut Carpenter \& Niem, (1998; 2001); Kailolla \& Tarp (1984); Allen (1999) dan de Bruin et al. (1994).

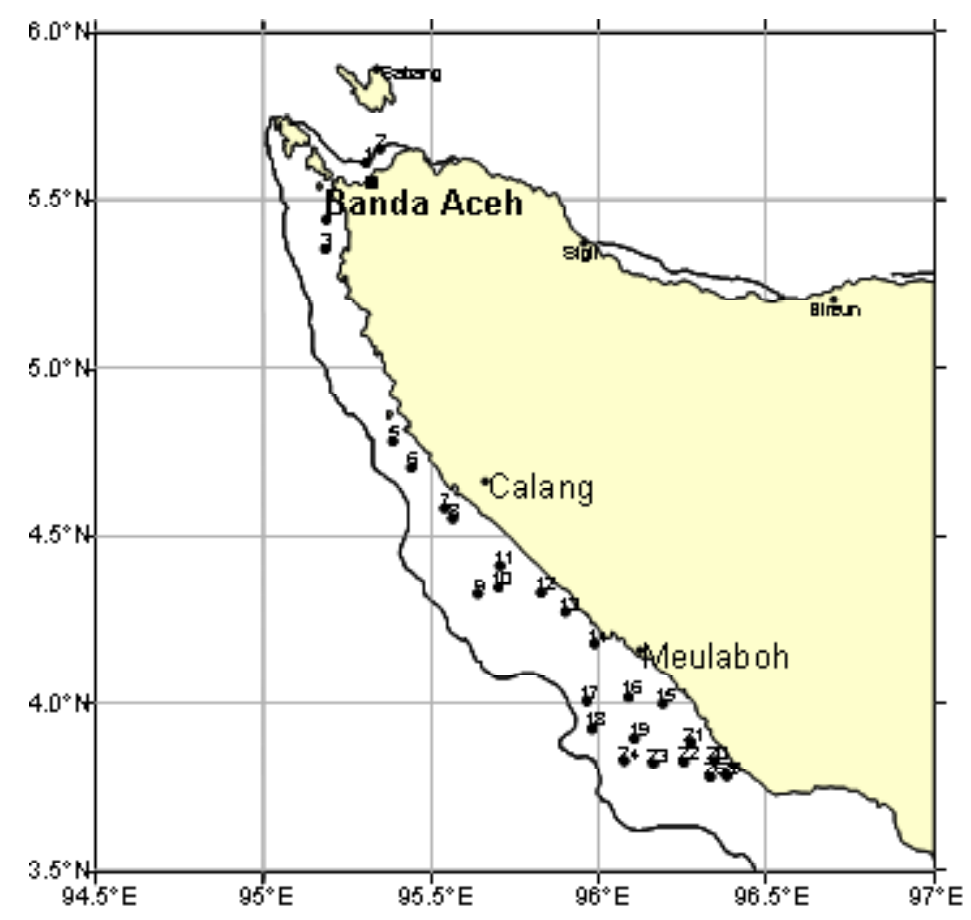

Gambar 1. Peta lokasi penelitian di perairan pantai barat Aceh (Nanggroe Aceh Darussalam). Figure 1. Map of survey location in west of Aceh waters (Nanggroe Aceh Darussalam). 

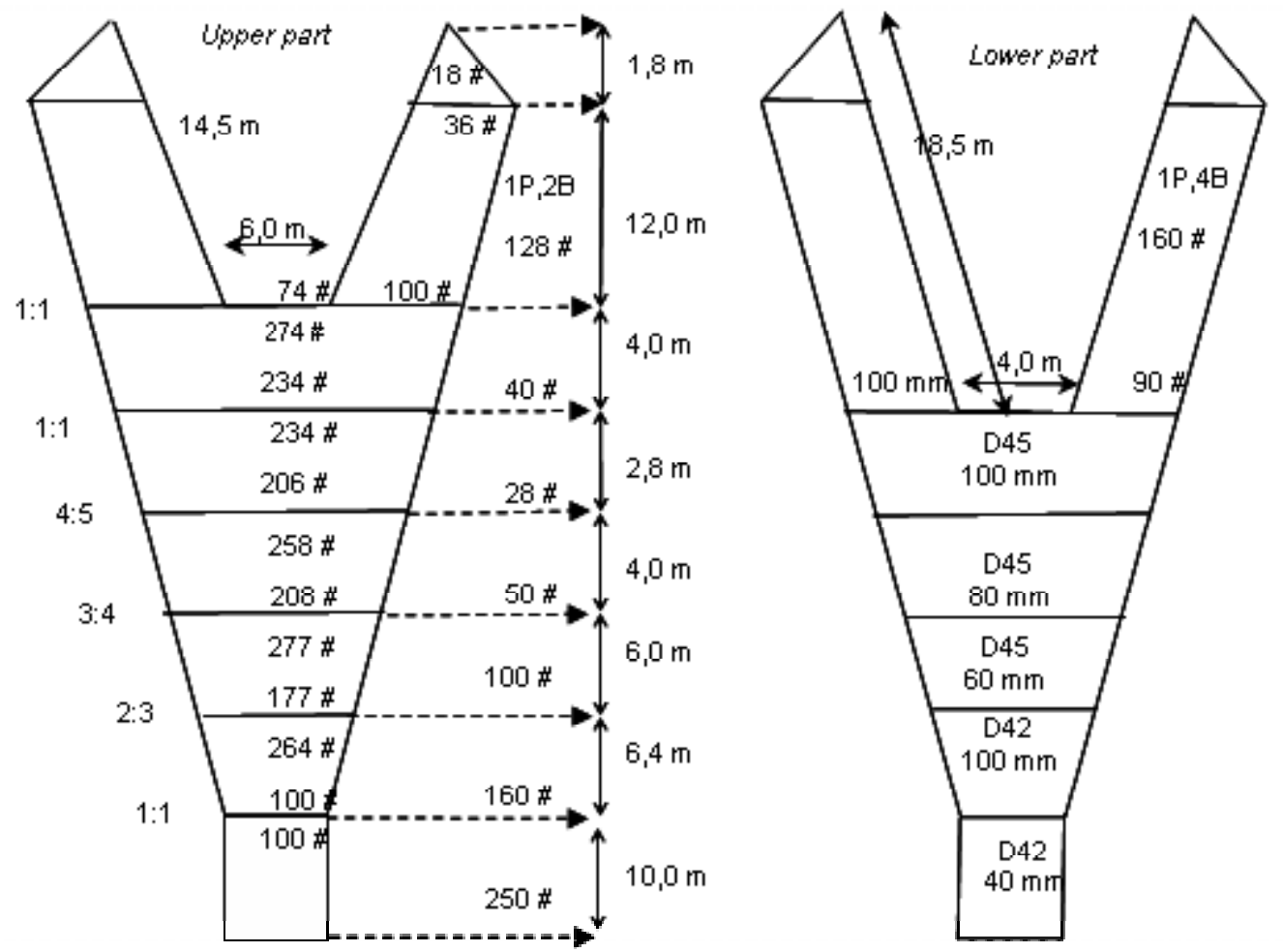

Gambar 2. Desain dan rancang bangun trawlyang digunakan untuk penelitian.

Figure 2. Design and lay out of bottom trawl used in the survey.

\section{HASIL DAN BAHASAN}

\section{Total Hasil Tangkapan}

Komposisi hasil tangkapan ikan dan udang hasil penelitian dikelompokkan berdasarkan pada kelompok demersal, pelagis, pari, udang, cumi, kerang, kepiting, dan lain-lain. Total hasil tangkapan terbesar didominansi oleh komoditas ikan demersal, yaitu $75,4 \%$ (tahun 2005) dan $75,8 \%$ (tahun 2006). Ikan demersal merupakan komoditas dominan, karena alat tangkap yang digunakan adalah alat tangkap ikan dasar (bottom traw). Ikan pelagis menempati urutan kedua setelah ikan demersal, yaitu 14,3\% (tahun 2005) dan $18,5 \%$ (tahun 2006). Tertangkapnya ikan pelagis dengan menggunakan bottom trawl disebabkan ikan tertangkap pada saat traw/ ditarik (haulling) atau pun pada saat pengambilan contoh pada perairan yang relatif dangkal di mana ikan pelagis berada pada lingkungan perairan tersebut. Kelompok komoditas ikan lainnya yang banyak tertangkap adalah ikan pari, yaitu $6,9 \%$ (tahun 2005) dan 1,2\% (tahun 2006). Komoditas unggulan penangkapan dengan menggunakan bottom trawl adalah kelompok udang, yang merupakan urutan keempat pada tahun 2005 (1,8\%), dan merupakan urutan ketiga pada tahun 2006 $(1,7 \%)$. Apabila dibandingkan dengan hasil tangkapan udang (Penaeidae) di perairan Arafura tahun 2003, juga sama karena hanya diperoleh persentase 1,2\% (Wedjatmiko, 2007). Komoditas lainnya seperti cumicumi, kekerangan, Ikan cucut, kepiting, dan teripang, persentasenya lebih kecil, yaitu kurang dari $1 \%$ (Tabel 1).

\section{Komposisi Hasil Tangkapan Udang}

Udang menduduki urutan keempat (tahun 2005) dan urutan ketiga (tahun 2006) dari total hasil tangkapan. Komposisi hasil tangkapan udang di perairan barat Aceh, berdasarkan pada famili diperoleh 6 famili pada tahun 2005, yaitu Penaeidae, Scyllaridae, Squillidae, Solenoceridae, Palaemonidae, dan Harpiosquillidae dan 7 famili pada tahun 2006, yaitu Penaeidae, Scyllaridae, Squillidae, Solenoceridae, Palaemonidae, Harpiosquillidae, dan Synaxidae. Famili udang yang paling dominan tertangkap adalah famili Penaeidae, baik pada tahun 2005 yaitu 86,3\%, maupun2006 $(69,9 \%)$ (Tabel 2$)$.

Jenis udang yang tertangkap di perairan barat Aceh secara keseluruhan adalah 20 spesies pada tahun 2005 dan 15 spesies pada tahun 2006. Jenis udang yang paling banyak tertangkap dari 20 spesies tersebut adalah jenis udang kelong. Hasil identifikasi berdasarkan pada Carpenter \& Niem (1998) menunjukkan bahwa udang kelong tersebut adalah 
Table 1. Komposisi hasil tangkapan berdasarkan kelompok komoditas, 2005-2006

Table1. Catch composition based on commodity group, 2005-2006

\begin{tabular}{clcccc}
\hline \multirow{2}{*}{ No. } & \multirow{2}{*}{ Komoditas/Commoduty } & \multicolumn{2}{c}{$\mathbf{2 0 0 5}$} & \multicolumn{2}{c}{$\mathbf{2 0 0 6}$} \\
\cline { 3 - 6 } & & $\mathbf{k g}$ & $\mathbf{6 g}$ & $\%$ \\
\hline 1. & Ikan demersal & 707,4 & 75,4 & $1.396,5$ & 76,8 \\
2. & kan pelagis & 134,4 & 14,3 & 335,9 & 18,5 \\
3. & Ikan pari & 64,5 & 6,9 & 30,0 & 1,7 \\
4. & Udang & 19,0 & 2,0 & 21,8 & 1,2 \\
5. & Cumi-cumi & 7,1 & 0,8 & 15,9 & 0,9 \\
6. & Kepiting & 1,3 & 0,1 & 10,6 & 0,6 \\
7. & Kekerangan & 3 & 0,3 & 4,6 & 0,3 \\
10. & lkan cucut & 1,3 & 0,1 & 2,9 & 0,2 \\
11. & Teripang & 0,4 & 0,0 & 0,0 & 0,0 \\
\hline
\end{tabular}

Tabel 2. Komposisi famili dan persentase hasil tangkapan udang, 2005-2006

Table 2. Catch composition and its percentage of shrimp family, 2005-2006

\begin{tabular}{|c|c|c|c|c|c|}
\hline \multirow{2}{*}{ No. } & \multirow{2}{*}{ Famili/Family } & \multicolumn{2}{|c|}{2005} & \multicolumn{2}{|c|}{2006} \\
\hline & & kg & $\%$ & kg & $\%$ \\
\hline 1. & Penaeidae & 16,4 & 86,3 & 20,9 & 69,9 \\
\hline 2. & Scyllaridae & 1,5 & 8,0 & 2,8 & 9,4 \\
\hline 3. & Squillidae & 0,6 & 3,0 & 2,3 & 7,5 \\
\hline 4. & Solenoceridae & 0,3 & 1,5 & 2,1 & 6,9 \\
\hline 5. & Palaemonidae & 0,2 & 0,8 & 1,6 & 5,5 \\
\hline 6. & Harpiosquillidae & 0,1 & 0,5 & 0,3 & 0,8 \\
\hline \multirow[t]{2}{*}{7.} & Palaemonidae & & & 0,0 & 0,1 \\
\hline & Jumlah & 19,1 & 100,0 & 30,0 & 100,1 \\
\hline
\end{tabular}

termasuk genus Penaeus dari famili Penaeidae, namun tidak teridentifikasi spesiesnya, sehingga udang kelong dikategorikan sebagai Penaeus sp. Salah satu karakteristik atau morfologi udang tersebut adalah mempunyai jumlah gigi pada rostrum $7 / 3$, yaitu 7 buah gigi di sisi atas rostrum dan 3 buah gigi di sisi bagian bawah rostrum. Warna badan coklat kemerahan, polos, halus, dan merata, dan tidak ada belang atau warna gelap terang lain. Laju tangkap udang kelong tersebut mencapai $6,9 \mathrm{~kg}$ per jam $(36,1 \%)$ dari total hasil tangkapan udang pada tahun 2005. Hasil tangkapan udang kelong tersebut merupakan jenis udang paling dominan (urutan pertama) pada tahun 2005 dan urutan kedua pada tahun 2006. Jenis udang lain yang dominan dan mempunyai ukuran besar (ekonomis) adalah Penaeus semisulcatus, Penaeus merguiensis, dan Metapenaus ensis (Tabel 3).

\section{Sebaran Frekuensi Panjang Badan}

Ukuran panjang total udang udang kelong yang tertangkap traw/ pada saat penelitian pada tahun 2005 maupun 2006 berkisar antara 8,0-17,0 cm. Apabila dibedakan berdasarkan pada jenis kelamin udang, ukuran udang betina lebih besar daripada udang jantan. Kisaran udang kelong betina $8,0-17,0 \mathrm{~cm}$ dengan dominansi pada ukuran $14,5 \mathrm{~cm}$. Ukuran udang tersebut mempunyai trend ukuran yang sama untuk udang yang tertangkap pada tahun 2005 maupun 2006. Hasil pengukuran udang jantan diperoleh kisaran panjang badan antara 8,0-13,0 cm dengan dominansi pada ukuran $11,5 \mathrm{~cm}$. Sama halnya dengan udang kelong betina, udang jantan yang tertangkap pada tahun 2005 dan 2006 mempunyai trend ukuran yang sama (Gambar 3).

Berdasarkan pada sebaran frekuensi panjang udang kelong (Gambar 3), ada indikasi bahwa udang kelong yang tertangkap pada tahun 2006 lebih besar daripada yang tertangkap pada tahun 2005 , baik untuk udang jantan maupun betina. Apabila mengkaitkan dengan adanya peristiwa tsunami yang terjadi pada akhir tahun 2004 yang menghancurkan semua sarana penangkapan udang, sehingga aktivitas penangkapan secara komersial belum pulih. Masa belum pulih aktivitas penangkapan udang tersebut memberi kesempatan udang untuk tumbuh lebih besar. Dengan demikian, ukuran udang yang tertangkap pada tahun 2006 cenderung lebih besar atau ada korelasi antara peristiwa tsunami dengan ukuran udang yang terdapat di perairan tersebut.

\section{Nisbah Kelamin}

Nisbah kelamin udang kelong yang tertangkap di perairan barat Aceh, antara jenis udang jantan dan betina diperoleh rasio untuk 1:2,1 tahun 2005 dan 
Tabel 3. Komposisi jenis dan persentase hasil tangkapan udang, 2005-2006

Table 3. Catch composition and its percentage of shrimp species, 2005-2006

\begin{tabular}{|c|c|c|c|c|c|}
\hline \multirow{2}{*}{ Tahun } & \multirow{2}{*}{ No. } & \multirow{2}{*}{ Spesies } & \multicolumn{2}{|c|}{ Hasil tangkapan/Catch } & \multirow{2}{*}{$\begin{array}{c}\text { Jumlahi/Number } \\
\text { (ekor) }\end{array}$} \\
\hline & & & $\mathbf{k g}$ & 听 & \\
\hline \multirow[t]{21}{*}{2005} & 1. & Penaeus sp. & 6,9 & 36,1 & 433 \\
\hline & 2. & Penaeus semisulcatus & 4,6 & 24,3 & 135 \\
\hline & 3. & Penaeus mergujensis & 1,7 & 8,7 & 42 \\
\hline & 4. & Thenus orientalis & 1,5 & 8,0 & 9 \\
\hline & 5. & Metapenaeus ensis & 1,5 & 7,9 & 15 \\
\hline & 6. & Metapenaeus affinis & 0,5 & 2,8 & 47 \\
\hline & 7. & Oratosquillina neps & 0,4 & 2,1 & 39 \\
\hline & 8. & Penaeus monodon & 0,3 & 1,6 & 2 \\
\hline & 9. & Solenocera crassicornis & 0,3 & 1,5 & 47 \\
\hline & 10. & Metapenaeus dobsoni & 0,3 & 1,3 & 72 \\
\hline & 11. & Penaeus canaliculatus & 0,2 & 1,2 & 5 \\
\hline & 12. & Parapenaeopsis spp. & 0,2 & 0,9 & 75 \\
\hline & 13. & Oratosquinina spp. & 0,2 & 0,8 & 7 \\
\hline & 14. & Exopalaemon styliferus & 0,2 & 0,8 & 71 \\
\hline & 15. & Metapenaeopsis banata & 0,1 & 0,6 & 13 \\
\hline & 16. & Metapenaeopsis toloensis & 0,1 & 0,6 & 16 \\
\hline & 17. & Harpiosquilia raphidae & 0,1 & 0,4 & 3 \\
\hline & 18. & Parapenaeus coromandelica & 0,0 & 0,1 & 5 \\
\hline & 19. & Trachypenaeus spp. & 0,0 & 0,1 & 3 \\
\hline & 20. & Metapenaeus spp. & 0,0 & 0,0 & 1 \\
\hline & & Jumlah & 19,0 & 100,0 & 1.040 \\
\hline \multirow[t]{16}{*}{2006} & 1. & Metapenaeus ensis & 11,5 & 38,3 & 485 \\
\hline & 2. & Penaeus sp. & 5,4 & 18,1 & 102 \\
\hline & 3. & Oratosquilina neps & 2,6 & 8,6 & 123 \\
\hline & 4. & Solenocera crassicornis & 2,1 & 6,9 & 292 \\
\hline & 5. & Parapenaeus coromandelica & 2,0 & 6,6 & 162 \\
\hline & 6. & Penaeus semisulcatus & 1,7 & 5,5 & 38 \\
\hline & 7. & Thenus orientalis & 1,6 & 5,5 & 11 \\
\hline & 8. & Panuoirus ornatus & 1,6 & 5,4 & 2 \\
\hline & 9. & Panuîrus polyphagus & 0,6 & 2,1 & 1 \\
\hline & 10. & Metapenaeusspp. & 0,4 & 1,2 & 26 \\
\hline & 11. & Harpiosquilla raphidae & 0,2 & 0,8 & 7 \\
\hline & 12. & Squilia sp. & 0,1 & 0,4 & 10 \\
\hline & 13. & oratosquiina perpensa & 0,1 & 0,4 & 7 \\
\hline & 14. & Metapenaeopsis toloensis & 0,0 & 0,1 & 5 \\
\hline & 15. & Exopalaemon styiferus & 0,0 & 0,1 & 13 \\
\hline & & Jumlah & 30,0 & 100,0 & 1.284 \\
\hline
\end{tabular}

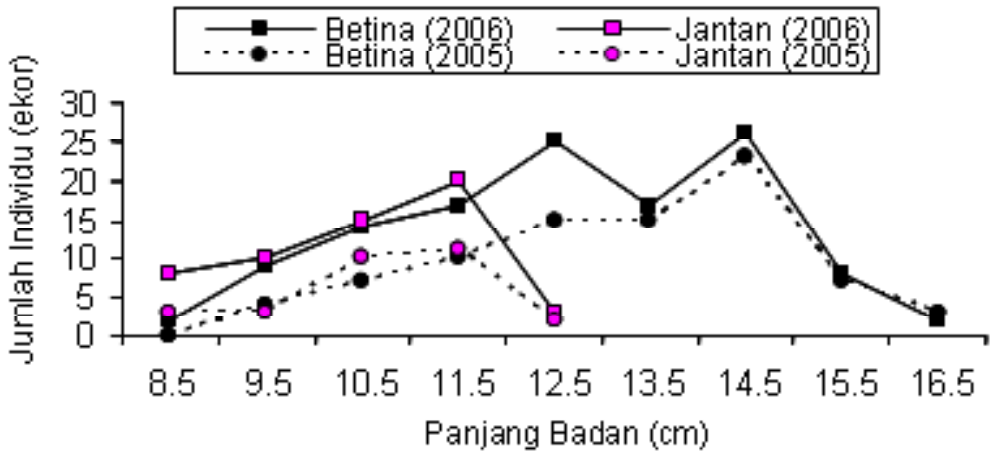

Gambar 3. Sebaran frekuensi panjang udang kelong jantan dan betina di perairan pantai barat Aceh.

Figure 3. Length frequency distribution of male and female udang kelong in western Aceh waters. 
Tabel 4. Rasio kelamin udang kelong di perairan barat Aceh (tahun 2005-2006)

Table 4. Sex ratio of udang kelong, in western Aceh water2005-2006

\begin{tabular}{|c|c|c|c|c|c|c|c|}
\hline \multirow{2}{*}{ No. } & \multirow{2}{*}{ Kelamin/Sex } & \multicolumn{2}{|c|}{$1974^{*}$} & \multicolumn{2}{|c|}{2005} & \multicolumn{2}{|c|}{2006} \\
\hline & & Ekor & $\%$ & Ekor & $\%$ & Ekor & $\%$ \\
\hline 1. & Jantan & 349 & 47,5 & 56 & 31,8 & 32 & 36,0 \\
\hline \multirow[t]{3}{*}{2.} & Betina & 386 & 42,5 & 120 & 68,2 & 57 & 64,0 \\
\hline & Jumlah & 735 & 100,0 & 176 & 100,0 & 89 & 100,0 \\
\hline & Rasio & \multicolumn{2}{|c|}{$1: 1,1$} & \multicolumn{2}{|c|}{$1: 2,1$} & \multicolumn{2}{|c|}{$1: 2,9$} \\
\hline
\end{tabular}

Keterangan/Remarks: * Badruddin \& Widodo (1974)

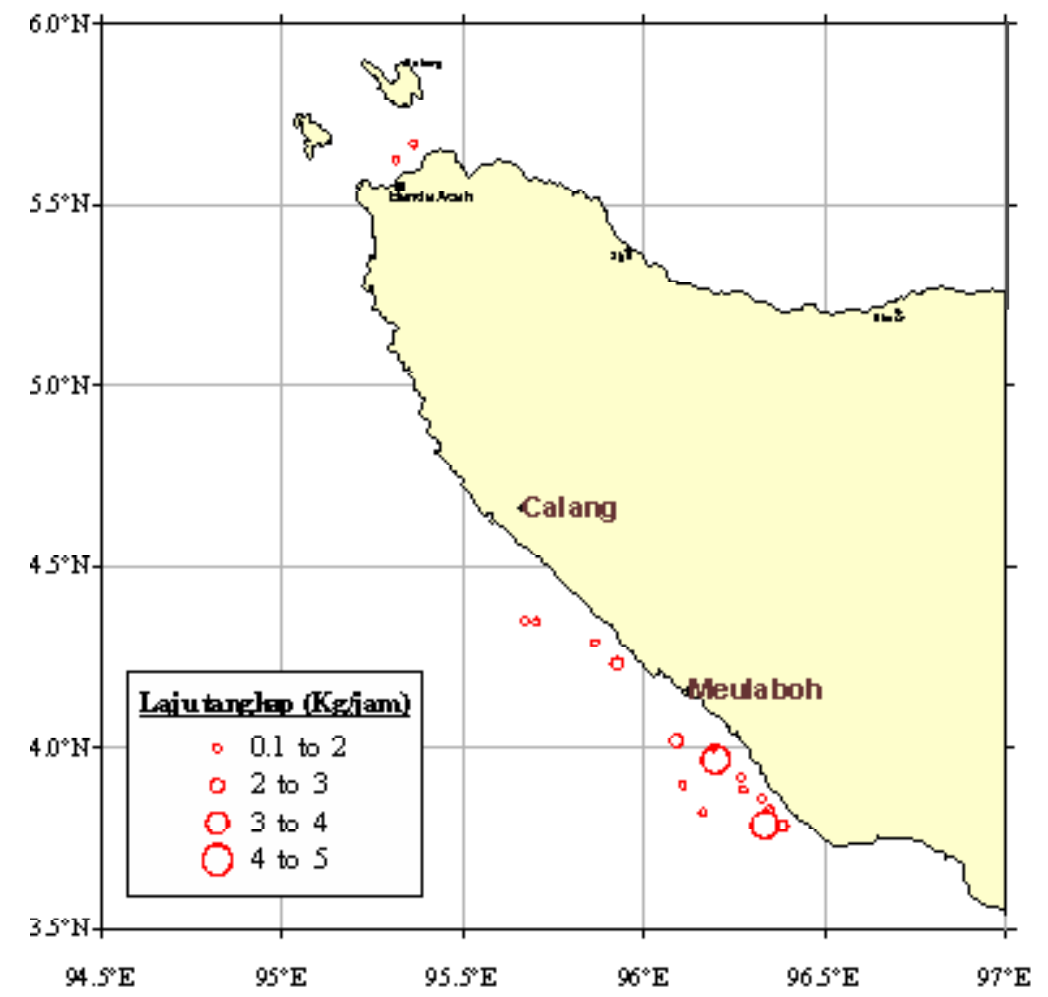

Gambar 5. Penyebaran sumber daya udang kelong di perairan barat Aceh.

Figure 5. Distribution of udang kelong resoures in western Aceh waters.

1:2,9 untuk tahun 2006 (Tabel 4). Nilai tersebut menunjukkan bahwa jumlah udang kelong betina yang tertangkap di perairan barat Aceh, lebih banyak daripada udang kelong jantan. Berdasarkan pada hal tersebut dapat mengindikasikan 2 kemungkinan, yaitu pertama bahwa memang benar keberadaan udang kelong betina di alam (perairan barat Aceh) 2 kali lipat lebih banyak daripada udang kelong jantan. Kedua bahwa udang betina lebih mudah tertangkap oleh alat tangkap trawl, jika diasumsikan bahwa populasi udang kelong jantan dan betina di alam adalah sama.

Apabila yang terjadi asumsi kedua, di mana udang kelong betina lebih rentan atau lebih mudah tertangkap, maka dikhawatirkan terjadi lebih tangkap (over fishing), karena udang kelong betina akan mudah tertangkap jaring dan tidak sempat reproduksi secara optimal. Oleh karena itu, nisbah kelamin udang kelong tersebut belum dapat dijadikan tolok ukur untuk antisipasi over fishing.

Nisbah kelamin udang kelong yang tertangkap di perairan barat Aceh pada tahun 1974 berbeda dengan hasil yang diperoleh tahun 2005 dan 2006 (Tabel 4). Nisbah kelamin udang kelong tahun 1974 cukup seimbang, sedangkan pada tahun 2005 dan 2006, udang betina 2 kali lebih besar daripada udang jantan.

Jika dibandingkan dengan nisbah kelamin udang jerbung di Laut Jawa, yaitu udang jerbung betina dibanding udang jerbung jantan $=1: 2,09$ (Wedjatmiko \& Yulianti, 2003). Hasil penelitian terhadap udang windu di perairan Meulaboh diperoleh sex ratio jantan : betina yang seimbang, yaitu 1,8:1 (Badruddin, 1977). 


\section{Penyebaran}

Penyebaran udang kelong ternyata tidak dijumpai di seluruh stasiun penelitian di perairan barat Aceh, melainkan hanya dijumpai pada beberapa stasiun penelitian, yaitu hanya 9 stasiun $(7,8$,12, 15, 20, $21,25,26,27)$. Posisi stasiun tersebut terletak di perairan pantai barat Calang-Sibolga dan sekitar, atau tepat pada koordinat antara lintang 03०47,237' N-

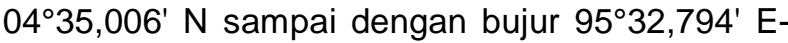
$96^{\circ} 22,833^{\prime}$ E. Secara visual, penyebaran sumber daya udang kelong di perairan barat Aceh (Gambar 5).

Berdasarkan pada Gambar 5, juga terlihat bahwa udang kelong lebih banyak tertangkap di perairan sebelah selatan Kota Meulaboh, dengan laju tangkap 4-6 kg per jam. Di perairan antara Calang dan Meulaboh serta di perairan sekitar Banda Aceh laju tangkap lebih rendah yaitu sekitar $1 \mathrm{~kg}$ per jam.

\section{KESIMPULAN}

1. Jumlah spesies udang yang tertangkap di perairan barat Aceh, diperoleh 20 spesies (tahun 2005) dan 15 spesies (tahun 2006).

2. Hasil tangkapan udang yang dominan pada tahun 2005 adalah udang kelong, yaitu 36,1\%. Pada tahun 2006 yang dominan tertangkap adalah udang dogol $38,3 \%$, yang diikuti oleh udang kelong $18,1 \%$.

3. Ukuran udang kelong yang tertangkap menunjukkan bahwa udang kelong betina lebih besar $(14,5 \mathrm{~cm})$ dibanding udang kelong jantan $(11,5 \mathrm{~cm})$.

4. Nisbah kelamin udang kelong yang tertangkap diperoleh rasio 1:2,1 (tahun 2005) dan 1:2,9 (tahun 2006) untuk udang jantan : udang betina.

5. Penyebaran udang kelong di perairan barat Aceh paling dominan tertangkap adalah di perairan sekitar Kota Meulaboh.

\section{PERSANTUNAN}

Kegiatan dari hasil riset tangkapan dan aspek biologi udang kelong, di perairan barat Aceh, T. A. 2005-2006, kerja sama antara Pusat Riset Perikanan Tangkap, Pusat Penelitian Oseanografi-Lembaga IImu Pengetahuan Indonesia dan Norwegia.

\section{DAFTAR PUSTAKA}

Badrudin. 1977. Studi pendahuluan tentang umur, pertumbuhan, sex ratio, dan kematangan ovari udang windu (Penaeus monodon Fab.) di perairan Meulaboh. Seminar II Perikanan Udang. Jakarta. Maret 1977. Prosiding Seminar I/ Perikanan Udang. Lembaga Penelitian Perikanan Laut. Jakarta.

Badrudin \& J. Widodo. 1974. Survei udang di pantai barat Sumatera. Laporan Penelitian Perikanan Laut. Lembaga Penelitian Perikanan Laut. Jakarta.

Carpenter, K. E. \& V. H. Niem. 1998-2001 (Vol.1-5). The Living Marine Reources of the Western Central Pacific. Species Identification Guide for Fishery Purposes. Food and Agriculture Organization of the United Nations. Rome.

De Bruin G. H. P., B. C. Russell, \& A. Bogusch. 1994. FAO species identification guide for fishery purposes. The Marine Fishery Resources of Sri Lanka. Food and Agriculture Organization of the United Nations. Rome.

Kailola, P. J. \& T. G. Tarp. 1984. Trawled Fishes of Southern Indonesia and Northwestern Australia. Australian Development Assistance Bereau. Directorat General of fisheries-Indonesia. German Agency for Technical Cooperation.

Naamin, N. 1992. Perkembangan perikanan udang di Indonesia. Prosiding Seminar II Perikanan Udang. Jakarta.

Naamin, N., F. Cholik, S. Ilyas, A. Dwiponggo, \& J. Widodo. 1992. Pedoman Teknis Pemanfaatan dan Pengelolaan Sumber Daya Udang Penaeid bagi Pembangunan Perikanan. Seri: Pengembangan Penelitian Perikanan No.PHP/KAN/PT/22/1992. Badan Penelitian dan Pengembangan Pertanian. Jakarta. 89 pp.

Ornamental Marine Fishes from Indonesia. 2005. White (Banana) Prawn, Udang Kelong, Penaeus indicus. (http://www. Omfi).

Sugeng, R. 2005. Udang Jenis Baru Siap Diluncurkan dari Aceh. Kompas. Edisi Hari Senin, 10 Oktober 2005. Jakarta. 
Suman, A. 1996. Status perikanan udang penaeid di perairan Aceh Barat. Benua Maritim Indonesia. Konsepsi Benua Maritim Indonesia untuk Mengaktualisasikan Wawasan Nusantara. Makassar. 18-19 Desember.

Wedjatmiko. 2007. Sebaran dan kepadatan udang mantis (Carinosquilla spinosa) di perairan Arafura. Pusat Riset Perikanan Tangkap. Jakarta. Jurnal Penelitian Perikanan Indonesia.13 (1): 61-69.
Wedjatmiko \& Yulianti. 2003. Beberapa aspek biologi udang jerbung (Penaeus merguiensis) di perairan Mayangan pantai utara Jawa Barat. Pusat Riset Perikanan Tangkap. Jakarta. Jurnal Penelitian Perikanan Indonesia. 9 (3): 27-34.

Widodo. 1977. Potensi udang di perairan Meulaboh atau Aceh. Seminar II Perikanan Udang. Jakarta. Maret 1977. Prosiding Seminar I/ Perikanan Udang. Lembaga Penelitian Perikanan Laut. Jakarta. 